\title{
Nitrogen applied in okra under non-tightness grown and residual fertilization
}

\author{
Marinice O Cardoso ${ }^{1}$; Rodrigo F Berni ${ }^{1}$ \\ Embrapa Amazônia Ocidental, C. Postal 319, 69010-970 Manaus-AM; marinice.cardoso@embrapa.br; rodrigo.berni@embrapa.br
}

\begin{abstract}
The aim of this study was to evaluate, in the Amazonian rainy season, the effect of nitrogen applied in okra under non-tightness grown and residual fertilization. The trial was carried out in the Embrapa Amazonia Ocidental, in Iranduba, Amazonas state, Brazil, between October/2010 and February/2011, in dystrophic Yellow Argisoil, medium texture, using pits with residual fertility. The experimental design was of randomized blocks with four repetitions (two lines with four plants, spacing of $1.5 \times 1.0 \mathrm{~m}$ ) and four main treatments (urea: $0.0 ; 20.0 ; 40.0$ and 60.0 g plant $^{-1}$ corresponding to $0.0 ; 60.0 ; 120.0$ and $180.0 \mathrm{~kg} \mathrm{ha}^{-1}$ of $\mathrm{N}$, respectively, in two portions) using cv Dardo. Besides two additional treatments: chicken manure (1.0 L pit ${ }^{-1}$, with the cv Dardo) and cv Santa Cruz-47 (with urea rate of $40.0 \mathrm{~g} \mathrm{plant}^{-1}$ ). Micronutrients in pits and dripping system irrigation were applied. All the studied traits had significant quadratic response with the increase of the urea rates. The highest estimated value for the plant height $(39.7 \mathrm{~cm})$, canopy diameter $(86.2 \mathrm{~cm})$, fruit number (36.0 un plant $\left.\mathrm{u}^{-1}\right)$, fruit average mass $(17.3 \mathrm{~g})$, harvest number within production cycle (26.4 un cycle $\left.{ }^{-1}\right)$ and of the yield $\left(4051 \mathrm{~kg} \mathrm{ha}^{-1}\right)$ were observed with (g plant ${ }^{-1}$ of urea): 48.3; 43.5; 38.5; 49.7; 32.7; and 40.5 , respectively. Those original traits contributed reasonably poised for plant overall performance (PC1), but subordinate there was antagonism between harvest number and fruit number versus fruit average mass and canopy diameter (PC2). The chicken manure showed positive response compared to the control treatment, but didn't differ from urea rates for all these characteristics. When compared to cv Dardo, the cv Santa Cruz-47 only presented higher values to canopy diameter and number of harvests. The economical efficiency maximum dose was $40.2 \mathrm{~g}$ plant ${ }^{-1}$ of urea $\left(120.6 \mathrm{~kg} \mathrm{ha}^{-1}\right.$ of $\mathrm{N}$ ), with net income per hectare equal to 2.09 tons of okra fruits.
\end{abstract}

Keywords: Abelmoschus esculentus, fertilization, organic manure, yield.

\section{RESUMO}

Nitrogênio aplicado à cultura do quiabeiro sob cultivo nãoadensado e adubação residual

Objetivou-se avaliar, no período chuvoso amazônico, o efeito do nitrogênio aplicado ao quiabeiro sob cultivo não-adensado e adubação residual. O ensaio foi conduzido na Embrapa Amazônia Ocidental, em Iranduba-AM, entre outubro/2010 e fevereiro//2011, em Argissolo Amarelo distrófico, textura média, utilizando-se covas com níveis residuais de fertilidade. O delineamento experimental foi em blocos casualizados com quatro repetições (duas linhas com quatro plantas, espaçadas de $1,5 \times 1,0 \mathrm{~m}$ ) e quatro tratamentos principais (ureia, em cobertura: 0,$0 ; 20,0 ; 40,0$ e 60 g planta $^{-1}$ correspondendo a 0,$0 ; 60,0$; 120,0 e $180,0 \mathrm{~kg} \mathrm{ha}^{-1}$ de $\mathrm{N}$, respectivamente, em duas parcelas), com a cv Dardo. Além de dois tratamentos adicionais, representados pelo esterco de galinha (1,0 L por cova, com a cv Dardo) e pela cv Santa Cruz-47 (com 40 g planta $^{-1}$ de ureia). As covas receberam micronutrientes e irrigação por gotejamento. As características avaliadas mostraram incrementos quadráticos com as doses de ureia. Os maiores valores da altura de planta $(39,7 \mathrm{~cm})$, do diâmetro de copa $(86,2 \mathrm{~cm})$, do número de frutos ( 36 unidades planta ${ }^{-1}$ ), da massa média de fruto (17,3 g), do número de colheitas no ciclo produtivo (26,4 unidades ciclo $\left.^{-1}\right)$ e da produtividade $\left(4051 \mathrm{~kg} \mathrm{ha}^{-1}\right)$ ocorreram com (g planta ${ }^{-1}$ de ureia): 48,3; 43,5;38,5 g; 49,7; 32,7; e 40,5, respectivamente. As características originais concorreram com razoável equilíbrio para o desempenho geral da planta (CP1), evidenciando-se, secundariamente, antagonismo entre colheitas por ciclo e frutos por planta contra a massa média de fruto e o diâmetro de copa (CP2). O esterco de galinha proporcionou desempenho idêntico ao da ureia e sobressaiu ao tratamento sem ureia, para todas as características. A cv Santa Cruz47 superou a cv Dardo somente para o diâmetro de copa e número de colheitas. A dose de máxima eficiência econômica foi 40,2 $\mathrm{g}$ de ureia planta-1 $\left(120,6 \mathrm{~kg} \mathrm{ha}^{-1} \mathrm{de} \mathrm{N}\right)$, com renda líquida por hectare de 2,09 toneladas de quiabo.

Palavras-chave: Abelmoschus esculentus, fertilização, adubação orgânica, rendimento.

(Recebido para publicação em 10 de agosto de 2011; aceito em 17 de setembro de 2012)

(Received on August 10, 2011; accepted on September 17, 2012)

$\mathrm{O}$ $\mathrm{kra}$ is originated from the African continent and it was introduced in Brazil by the slaves (Filgueira, 2008). It is one of the most well adapted vegetable fruit to tropical conditions, and it has excellent nutritive value. The fruits are hairy, capsule type, widely used in Brazilian cuisine, especially in Bahia, Maranhão and Minas Gerais states cuisines. According to FAO (2003), the fruits and leaves contain, in $100 \mathrm{~g}$ respectively: proteins ( $2.1 \mathrm{~g}$ and $4.4 \mathrm{~g}$ ); fats $(0.2 \mathrm{~g}$ and $0.6 \mathrm{~g})$; carbohydrates $(7.0 \mathrm{~g}$ and $9.0 \mathrm{~g})$; betacarotene $(190 \mu \mathrm{g}$ and $730 \mu \mathrm{g})$; vitamins $\mathrm{B}_{1}, \mathrm{~B}_{2}$ and $\mathrm{B}_{6}$ (0.04 $\mu \mathrm{g}$ and $0.25 \mu \mathrm{g} ; 0.08 \mu \mathrm{g}$ and 2.80 $\mu \mathrm{g} ; 0.22 \mu \mathrm{g}$ and $0.0 \mu \mathrm{g})$, besides niacin, $\mathrm{B}_{5}(0.6 \mathrm{~g}$ and $0.2 \mathrm{~g})$ and vitamin $\mathrm{C}(47$ $\mathrm{mg}$ and $59 \mathrm{mg}$ ), as well as calcium (84 $\mathrm{mg}$ and $530 \mathrm{mg}$ ) and iron (1.2 and 0.7 $\mathrm{mg}$ ). From the okra seeds, aromatic edible oil is extracted, containing, mainly, monounsaturated fatty acids, like oleic acid and palmitic acid, and also proteins of high biological value (Guimarães, 2008). The okra also contains medicinal properties, helping 
people with digest system problems, because of its refreshing, emollient and laxative actions (Gonsalves, 2001), besides being beneficial to the heart, because of the niacin, which helps to raise good cholesterol levels (HDL) and decrease triglycerides (Mamber, 2011). The tea from the leaves is recommended for the disorders of the respiratory system (Gonsalves, 2001). Recently, this species has become important in cosmetics industry, with fruit extract in the composition of products like shampoos and hair conditioner. It also has potential to be used like source of paper pulp and fuel or biomass and animal food (Sediyama et al., 2009).

Nitrogen plays a fundamental role in growth and yield of vegetable crops, however, the absorption varies according to the species and among genotypes of the same species. The direct positive effect of this macronutrient on the herbaceous species yield is known, for the fact that the harvested products are leaves, tender stems and inflorescences. Also in vegetable fruit, among others, a direct and positive correlation between aboveground part and yield is noticed with balanced $\mathrm{N}$ supply (Filgueira, 2008). In okra, the omission of $N$ in the nutritive solution caused a decrease in the leave size, the stem diameter and the height of plant, besides the intense falling of floral buds, avoiding fruiting (Costa et al., 1981). The reason is that after absorption, $\mathrm{N}$ is introduced as a free ion in the vacuole and incorporated into organic compounds, represented mainly by amino acids and proteins, besides being an integral part of nucleic acid and chlorophyll molecule (Taiz $\&$ Zeiger, 2004). Thus, the balanced supply of $\mathrm{N}$ causes positive effect on the growth of the aboveground part, the root and on the quality of the vegetables (Filgueira, 2008). Furthermore, this nutrient stimulates the absorption of other nutrients. $\mathrm{N}$ has a direct effect in the source-sink relationships, because it changes the distribution of assimilates between reproductive and vegetative parts (Queiroga et al., 2007).

The large reservoir of $\mathrm{N}$ is the atmosphere, and the two main processes of transferring it to the soil are industrial fixation (as fertilizers) and biological fixation. However, due to the denitrification process, a large proportion of fixed $\mathrm{N}$ is lost to the atmosphere, so that, it becomes a virtually inexhaustible storehouse of this nutrient (Gomes et al., 2000). The inorganic nitrogen fertilizers include, mainly, sodium nitrate, ammonium sulphate, ammonium nitrate, urea, anhydrous ammonia, ammonium chloride and calcium nitrate (Gomes et al., 2000; Malavolta et al., 2002). Some nitrogen fertilizers in which $\mathrm{N}$ is only present as nitrate have alkalinic behavior, however, others acidify the soil through reactions after application, because of the release of hydrogen ions which diminishes the soil $\mathrm{pH}$ (Malavolta et al., 2002). Urea has one of the lowest levels of acidity, increasing very little soil acidity (Sousa \& Lobato, 2004). Nevertheless, the effects on the crops depend on the type of soil and climate. On the other hand, a way of adding $\mathrm{N}$ to soil is through organic fertilization with animal manure that, according to Almeida (1991), is widely used to grow vegetables, for their positive effects on the soil conditioning and nutrient supply, especially $\mathrm{N}$.

In the Amazonas state, the production system used for okra crop by farmers is the open field system, and according to IDAM (2010) the produced quantities, in variable number of cycles, reached in $20104,535.36 \mathrm{t}$ of fruit. Since it is a well adapted vegetable to the regional climatic conditions, the soil management takes priority in improving the environment aiming to take care of specific requirements. The manure practice of a vegetable crop involves interactions among soil, fertilizer and plant (Andriolo, 2002), and N dynamics in soil is characterized by intense and quick transformations, which are influenced by temperature, humidity, aeration, wetting and drying cycles in soil, type of organic material, microorganisms, $\mathrm{pH}$, tillage and soil fertility (Tomé Junior, 1997). N application should be fractionated, part at planting complemented with urea rates in side dressing (Filgueira, 2008), which is justified by the possibility of high doses momentarily increase the salt concentration of the soil solution in contact with the seedlings or seeds newly germinated, and because this nutrient is easily leached, particularly in sandy soils (Ribeiro et al., 1999). The efficiency of the nitrogen fertilizers is affected by both low and excessive soil moisture, because the need of water for solubilization and the $\mathrm{N}$ loss from the soil through leaching and volatilization processes (Raij, 1991; Duarte, 2006).

Because it is located in Western Amazon, the state of Amazonas integrates the brazilian humid tropics, hot and humid weather, with high rainfall at least one part of the year with the months of April and October constituting transition to dry and rainy seasons, respectively (Fisch et al. 1998). Therefore, in the months of high rainfall in the regional conditions, the losses of applied $\mathrm{N}$ may be enhanced, causing loss in the agronomic performance of vegetable crops. Concomitantly, the volatilization of $\mathrm{NH}_{3}$ from urea increases with temperature, through increasing the rate of hydrolysis, providing an increased amount of volatile $\mathrm{NH}_{3}$ (Longo \& Melo, 2005; Duarte, 2006). These aspects emphasize the need to correctly estimate the doses of fertilizer to use, to better adjust supply and demand of nutrients. Nutrient deficiency compromise the efficiency of the whole crop process (Liebig's Law of the Minimum), and excesses interfere negatively on the mechanisms of absorption, besides predisposing plants to the attack by pests and pathogens (Andriolo, 2002). Thus, this work was carried out aiming to evaluate, in the Amazonian rainy season, the effects of the doses of urea in topdressing on attributes of growth and production of hybrid okra cultivar Dardo, under non-tightness condition and residual fertilization, besides additional studies including the non-hybrid cultivar Santa Cruz-47 and chicken manure.

\section{MATERIAL AND METHODS}

The trial was carried in Embrapa Amazônia Ocidental, Iranduba county, Amazonas state, between October $/ 2010$ to February/2011. During the trial, the following average monthly temperature, rainfall and relative humidity were 
observed, respectively: $26.5^{\circ} \mathrm{C} ; 250.84$ $\mathrm{mm}$; and $87.26 \%$. The experiment was carried out in dystrophic Yellow Argisoil, medium texture, with traces of indigenous action. The land remained free of cultivation for five years and, in this condition, the soil showed the following chemical characteristics, at a depth of $0.0-20 \mathrm{~cm}: \mathrm{pH}\left(\mathrm{H}_{2} \mathrm{O}\right)=5.2$; $\mathrm{MO}\left(\mathrm{g} \mathrm{kg}^{-1}\right)=22.23 ; \mathrm{P}=53 \mathrm{mg} \mathrm{dm}{ }^{-3}$; $\mathrm{K}=26 \mathrm{mg} \mathrm{dm}^{-3} ; \mathrm{Ca}=1.94 \mathrm{cmol} \mathrm{dm}^{-3}$; $\mathrm{Mg}=1.05 \mathrm{cmol}_{\mathrm{c}} \mathrm{dm}^{-3} ; \mathrm{Al}=0.0 \mathrm{cmol}_{\mathrm{c}}$ $\mathrm{dm}^{-3} ; \mathrm{SB}=3.06 \mathrm{cmol}_{\mathrm{c}} \mathrm{dm}^{-3} ; \mathrm{V}=37.2 \%$. However, the planting pits showed some residual fertility level, from recent cucurbit crops, characterized by chemical analyses of samples formed by sub sampling of these pits $(0.0-20 \mathrm{~cm})$ : $\mathrm{pH}\left(\mathrm{H}_{2} \mathrm{O}\right)=6.52 ; \mathrm{MO}\left(\mathrm{g} \mathrm{kg}^{-1}\right)=37.44$; $\mathrm{P}=690 \mathrm{mg} \mathrm{dm}^{-3} ; \mathrm{K}=240 \mathrm{mg} \mathrm{dm}^{-3} ; \mathrm{Ca}=$ $4.55 \mathrm{cmol} \mathrm{dm}^{-3} ; \mathrm{Mg}=1.67 \mathrm{cmol} \mathrm{dm}^{-3}$; $\mathrm{Al}=0.0 \mathrm{cmol}_{\mathrm{c}} \mathrm{dm}^{-3} ; \mathrm{SB}=7.10 \mathrm{cmol}_{\mathrm{c}} \mathrm{dm}^{-}$ 3; $\mathrm{V}=69.03 \%$. However, micronutrients were added to the planting pit, applying $10 \mathrm{~g}$ of Fritted Trace Elements (FTE) BR-12 per pit. The experimental design was in randomized blocks with four replications. The treatments were divided in main treatments and additional treatments. The main treatments corresponded to urea rates in side dressing: $0.0 ; 20.0 ; 40.0$ and 60 $\mathrm{g}$ per pit $(0.0 ; 60.0 ; 120.0$ and $180.0 \mathrm{~kg}$ $\mathrm{ha}^{-1}$ of $\mathrm{N}$, respectively), with cv Dardo. Whereas the additional treatments were: TA (chicken manure: 1.0 L per pit, with cv Dardo) and TB (40 g of urea in side dressing per pit, with cv Santa Cruz-47). The plot had eight pits with one plant each, two lines spaced $1.5 \times 1 \mathrm{~m}$.

The doses of urea were split into two equal parts, with applications at five and twenty days after seedling transplanting, which were prepared on polystyrene tray of 72 cells containing substrate acquired in the local market. The transplanting of a cell with two seedlings was made when they had four true leaves, thinning was carried out, subsequently. The distribution of fertilizers was held in the wet track generated by the issuers of the irrigation drip tape, grooved at four points, fairly distanced from the stem of each plant, two on each side, then making up the dressing of the fertilizer with the soil. The drip tape had emitters every $10 \mathrm{~cm}$ (flow rate of $10.6 \mathrm{~L} / \mathrm{h} /$ meter) and the irrigation time occurred once a day for 25 minutes. This was necessary only in the beginning of the crop cycle, since the rainfall season started in November. Two weedings were performed, one with a motorized manual mower in the total area of the trial and another one with hoe in the rows with cultivation. The crickets (Gryllus assimilis), which attacked in the initial period of the cultivation, were controlled with two applications of deltamethrin directed to the collar of the plants, this way, they produced a repellent effect for some days and allowed the growth of the plants, which started to tolerate the damage caused by insects.

At 30 days after the first application of urea, the two central plants in the plot were measured for height (from the collar to the insert of the last leaf of the highest stem) and canopy diameter (in the height of the larger line segment parallel to the rows in the plot), using a tape measure.

The harvest time occurred at 105 days, with an average frequency of three times a week, gauging up to the final total number of harvests during production cycle. The fruit harvest began with cv Dardo and cv Santa Cruz-47, respectively, at 30 and 70 days after the seedling transplanting. During the measurement of the number and weight of fruits, the quality of the fruit for consumption was also verified (tender, well filled, firm), and if the tip would break easily. The fruit which tip simply bended, showing that they were withered or very fibrous, were separated.

The data analyses were evaluated using the software IRRISTAT 5.0. The main treatments were tested using polynomial regression, and the additional treatments, by contrast, using the $\mathrm{F}$ test ( $5 \%$ probability). The main component analysis was applied to the correlation matrix of the evaluated traits (Araújo \& Coelho, 2009), only in the main treatments, considering the eigenvalues of the correlation matrix $(\lambda)$ up to 0.60 . The economical efficiency maximum dose of manure for fruit production was determined, using for currency to pay for the input, the agricultural product itself (Raij, 1991). The equivalence relationship "price of $\mathrm{kg}$ of urea (c)/price of $\mathrm{kg}$ of fruit-level producer (v)" equals 0.98. Equating the first derivate of the regression equation for yield $(\mathrm{a} 1+2 \mathrm{a} 2 \mathrm{x})$ to the equivalence relation $(\mathrm{c} / \mathrm{v})$, the relation obtained $\left[\mathrm{x}^{\prime}=\right.$ a1 - (c/v)/ 2(-a2)] was used to calculate DMEE. The net income obtained per hectare was also calculated using this price relationship, and in other relationships based on the variation of the price of the kilogram of okra fruit, resulting from the supply of the regional market. Fixed cost for the production system used in the trial was determined according to the methodology proposed by CONAB (2010).

\section{RESULTS AND DISCUSSION}

Effect of dose - The doses of urea had quadratic effect for all the traits evaluated (Figure 1).

The highest value for the plant height $(39.7 \mathrm{~cm})$ occurred with application of $48.3 \mathrm{~g} \mathrm{plant}^{-1}$ of urea (Figure 1A). Nitrogen, provided by urea, participates in the synthesis of organic compounds constituents of the plant structure, thus it is responsible for attributes related to plant architecture (Taiz \& Zeiger, 2004), however, in excess it is restrictive (Fontes, 2005; Filgueira, 2008). The increase in the height of plant until the dose correspondent for its maximum value, confirms the observations made by Costa et al. (1981), which the omission of $\mathrm{N}$ from the nutrient solution negatively affected this okra trait.

The highest canopy diameter (86.2 $\mathrm{cm}$ ) occurred applying $43.5 \mathrm{~g} \mathrm{plant}^{-1}$ of urea. (Figure 1B). The linear increase, in fitted equation, was considerable $(+1.5056)$, certainly because of the fact that $\mathrm{N}$ increases the leaf expansion and size of the stems of the plants. The stem of okra develops with marked apical dominance, having few side branches which arise near the base and produce leaves and fruits. Therefore, the supply of $\mathrm{N}$ promotes, besides the increase of stem height, also the lateral increase, consequently, increasing the plant architecture, and, this way, influencing the canopy diameter. Filgueira (2008) states that the lateral branches are less frequent when planting density is increased. 


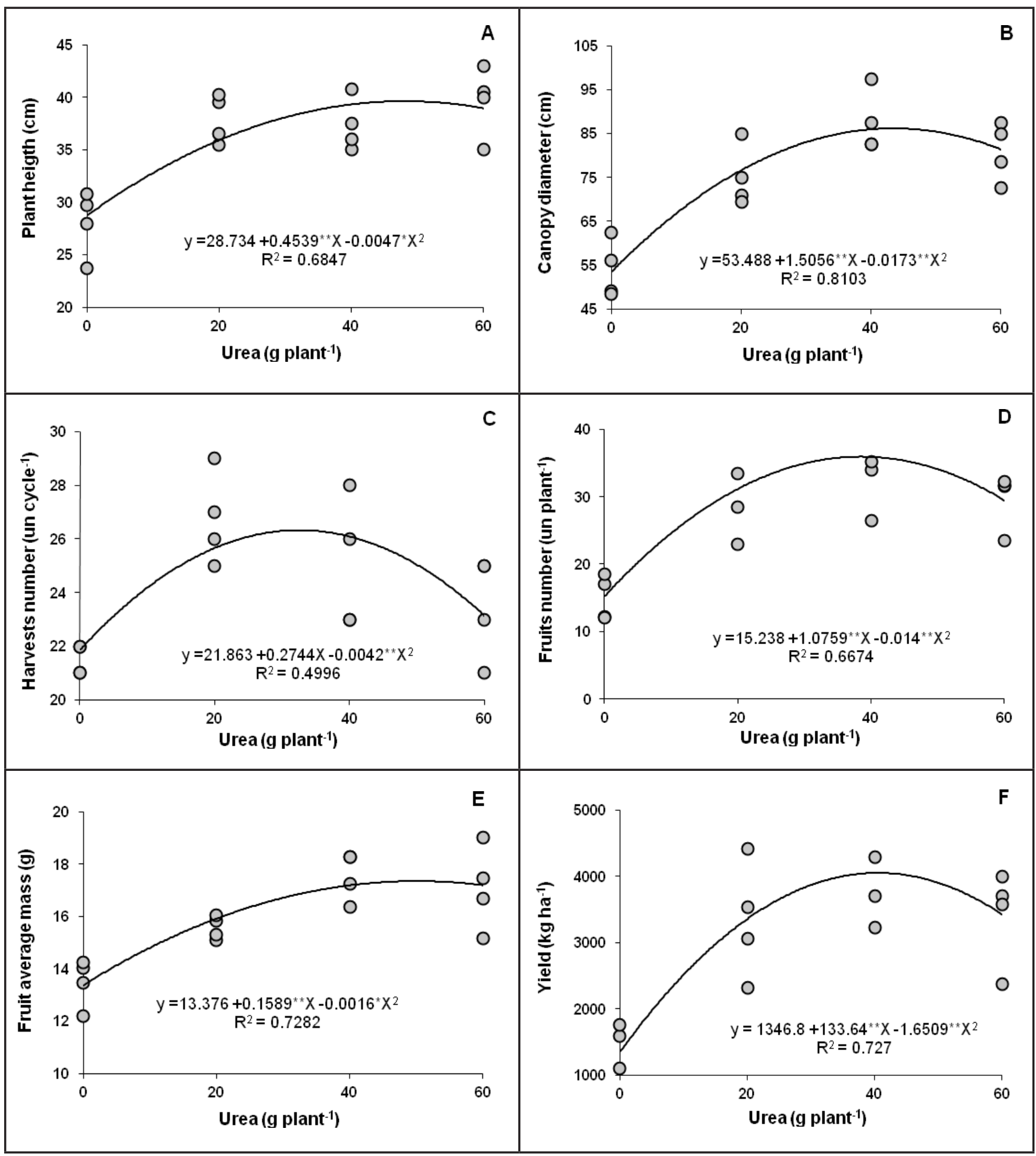

Figure 1. Plant height, canopy diameter, harvests number, fruits number, fruit average mass, and yield depending on urea doses. ${ }^{* * *}$ Significant at $1 \%$ and $5 \%$ of probability, respectively, by $\mathrm{F}$ test (altura de planta, diâmetro de copa, número de colheitas, número de frutos, massa média de fruto e produtividade em função de doses de ureia. ${ }^{* * *}$ significativo a $1 \%$ e $5 \%$ de probabilidade, respectivamente, pelo teste F). Manaus, Embrapa Amazônia Ocidental, 2010.

The maximum fruits number (36 units plant ${ }^{-1}$ ) was obtained with 38.5 g plant $^{-1}$ of urea (Figure 1D), thus, at higher doses, $\mathrm{N}$ negatively affected this trait. This nutrient promotes exceptional morphophysiological changes in plant, with a possibility of changing the number of fruits (Marschner, 1995). In accordance to the results obtained in this trial, green pepper showed the same quadratic response, for number of fruits per plant, when subjected to increasing doses of $\mathrm{N}$ (Campos et al., 2008). On the other hand, the dose which promotes the maximum number of fruits per plant is lower than the ones responsible for the highest values of the height of plant and canopy diameter. 


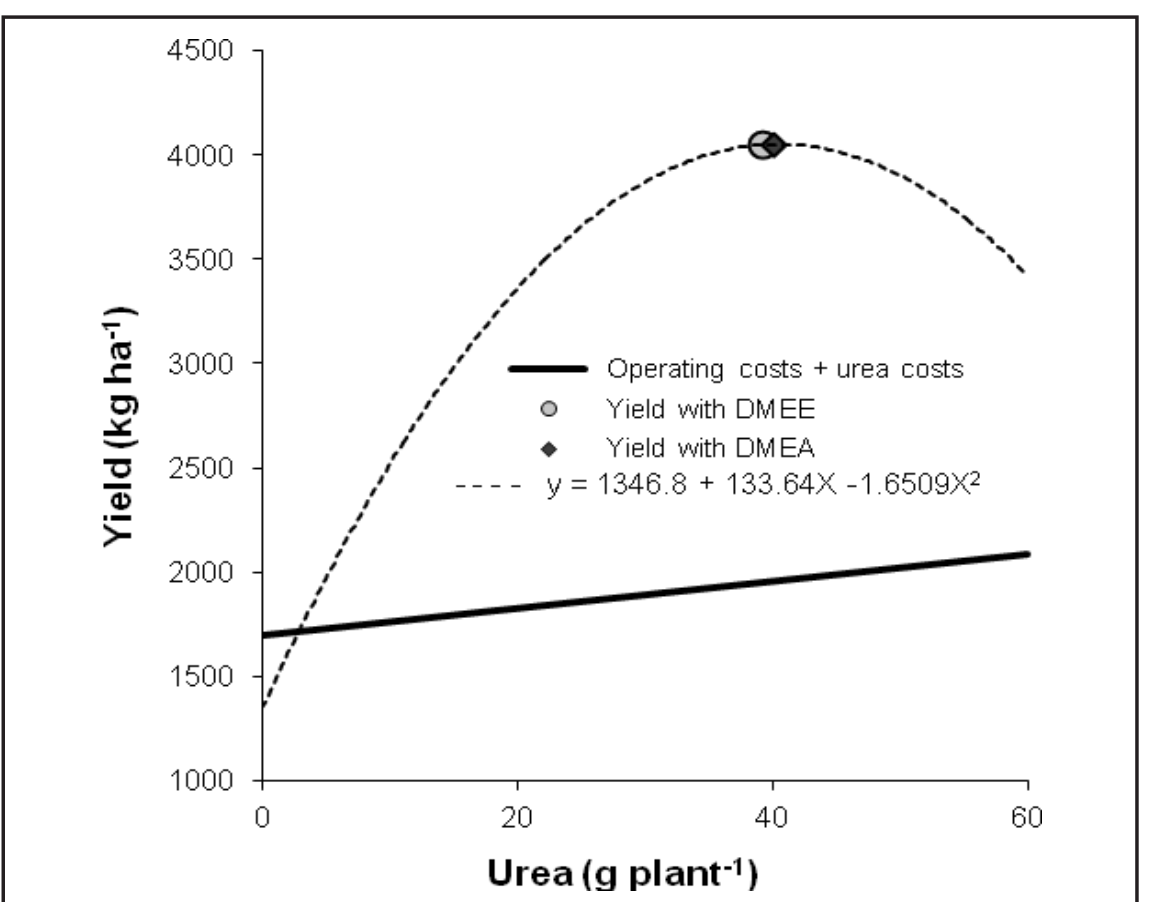

Figure 2. Economical efficiency maximum dose (DMEE) of urea in topdressing, nearly equal agronomic efficiency maximum dose (DMEA), of okra yield under non-tightness spacing and residual fertilization, using equivalence relation " $\mathrm{kg}$ of urea price $/ \mathrm{kg}$ of fruits price in farmer condition" equal 0.98 [dose de máxima eficiência econômica (DMEE) de ureia em cobertura, muito próxima da dose de máxima eficiência agronômica (DMEA), para a produtividade do quiabeiro sob espaçamento não-adensado e adubação residual, utilizando relação de equivalência "preço do $\mathrm{kg}$ de uréia/preço do $\mathrm{kg}$ de frutos em nível de produtor" igual a 0,98]. Manaus, Embrapa Amazônia Ocidental, 2010.

This certifies that taller plants or the ones with higher canopy diameter were not responsible for the highest number of fruits per plant. Considering that the excess of $\mathrm{N}$ promotes vegetative growth at the expense of reproductive (Mengel \& Kirkby, 1987; Fontes, 2005), it is possible to suggest a slight negative interaction effect between the increased plant architecture and the number of fruits per okra plant.

The fruit average mass showed maximum value $(17.3 \mathrm{~g})$ with $49.7 \mathrm{~g}$ plant $^{-1}$ of urea (Figure 1E). This mass required, practically, $10 \mathrm{~g}$ of urea beyond what was necessary for the number of fruits per plant ${ }^{-1}$ to achieve maximum value (36 units plant ${ }^{-1}$ ). Considering that the fruits are the strongest sinks for assimilates, and that the emergence of a new fruit competes more with the remaining fruits than with the vegetative organs (Duarte \& Peil, 2010), the conclusion is that from the dose which the number of fruits per plant started to decrease, more fruit average mass, the number of fruits per plant was considered decisive for its value. On a clayey typic acrorthox in the state of Amazonas, the yield in different genotypes of okra fertilized with chicken manure and $\mathrm{PK}$, ranged from $4.2 \mathrm{tha}^{-1}\left(420 \mathrm{~g}_{\text {plant }}{ }^{-1}\right)$ to $7.1 \mathrm{t} \mathrm{ha}^{-1}$ to $\left(710 \mathrm{~g} \mathrm{plant}^{-1}\right)$, with two applications of $5 \mathrm{~g}$ of dressing of urea (Cardoso, 2001). The contribution of $\mathrm{N}$ by chicken manure (27.6 $\left.\mathrm{g} \mathrm{kg}^{-1}\right)$, commonly used in great quantities ranging from 5 to 10 t ha-1 (Ribeiro et al., 1999), makes the dose of mineral $\mathrm{N}$ decrease. Besides the contribution of $\mathrm{N}$, the organic matter acts on nutrient retention and on the decrease of leaching (Bayer \& Mielniczuk, 1999). So, during the rainfall in the Amazon, besides other benefits, the organic manure may contribute to decrease the leaching of the applied N.

Principal component analysis - The principal component analysis allowed identify two principal components, which represent $92.18 \%$ of total variance of the original traits (Table 1). The principal component 1 (PC1) is the most important since it explains $82.27 \%$ of accumulated variance, whereas the principal component 2 (PC2) only explains $9.91 \%$ of total variance.

The $\mathrm{PC} 1$ is an average indicator for the original variables related to architecture and yield of the plant, where coefficients constitute multivariate means of the contributions. The very close values of these contributions, all with a positive sign $(0.409 ; 0.423$; $0.356 ; 0.435 ; 0.374$ and 0.445$)$, show a reasonable balance of the original traits in competing for the overall plant performance.

The principal component 2 (PC2), meaning the antagonism between the traits with high and positive coefficients (harvests number per production cycle $=0.730$; fruits number $=0.211$ ) against traits with high and negative coefficients (fruit average mass $=-0.605$; canopy diameter $=-0.218$ ), showed that the increase of variables with a positive sign results in a decrease of those with negative sign and vice versa. However, according to the highest coefficients, the variables harvests number per production cycle $(0.730)$ and fruit average mass $(-0.605)$ show the 
Table 1. Eigenvectors in two principal components ( $\mathrm{PC} 1$ and $\mathrm{PC} 2)$ of the growth and yield characteristics on okra [autovetores em dois componentes principais (CP1 e CP2) das características do crescimento e de produção em quiabeiro]. Manaus, Embrapa Amazônia Ocidental, 2010.

\begin{tabular}{lcc}
\hline \multirow{2}{*}{ Original characteristics } & \multicolumn{2}{c}{ Principal components } \\
\cline { 2 - 3 } & PC1 & PC2 \\
\hline Plant height & 0.409 & -0.099 \\
Canopy diameter & 0.423 & -0.218 \\
Harvests number & 0.356 & 0.730 \\
Fruits number & 0.435 & 0.211 \\
Fruit average mass & 0.374 & -0.605 \\
Yield & 0.445 & 0.017 \\
$\lambda$ & 4.940 & 0.600 \\
\hline VA $(\%)$ & 82.27 & 92.18 \\
\hline
\end{tabular}

$\lambda=$ correlation matrix autovalue; $\mathrm{AV}=$ accumulated variance $(\lambda=$ autovalor da matriz de correlação e VA= variância acumulada).

highest power to change this principal component, which is secondary to PC1.

Therefore, in this $\mathrm{PC} 2$, if the number of harvests per production cycle increases, the fruit average mass decreases, whereas the opposite is true. This is because the fruits are the major sinks for assimilates and the emergence of a new fruit competes more with the remaining fruit than with the vegetative organs (Duarte \& Peil, 2010). Thus, increasing the fruits number per plant, fewer assimilates remain available for fixed fruits per plant, contributing for the decrease of their average mass. The antagonic coefficients for the variables fruits number $(0.211)$ and the fruit average mass $(-0.605)$ confirm these results. In the competition of harvests number $(0.730)$ and fruits number
(0.211) with canopy diameter $(-0.218)$, in which the discrete power of influence of this latter trait is important, however, the interference of lateral branches on these attributes is suggested. Probably, because if the plant architecture rises too much, like in high density plantations, self-shading may have a negative effect on the photosynthetic rate of each plant, to the detriment of harvests number and fruits number.

Additional treatment effect Considering the additional treatments, three contrasts involving these treatments were studied (TA: chicken manure, cv Dardo; TB: $40 \mathrm{~g}_{\text {plant }}{ }^{-1}$ of urea, cv Santa Cruz-47) and principal treatments (TS: without added urea, cv Dardo and TC: $40 \mathrm{~g}$ plant $^{-1}$ of urea, $\mathrm{cv}$ Dardo), described in Table 2.
In contrast between $\mathrm{TA}$ and $\mathrm{TC}$, no significance of absolute difference (|ŷl) was observed among the average treatments related to all the traits. However, the chicken manure (1.01 per pit) promoted to okra Dardo conditions for identical performance to that obtained with the intermediate dose of urea $\left(40 \mathrm{~g}_{\text {plant }}{ }^{-1}\right)$.

On the other hand, TA (chicken manure) overcame TS (without added urea) for all the traits, which confirms the reports of Sediyama et al. (2009) about the excellent crop response to organic fertilization. It is noteworthy that the contribution of $\mathrm{N}$ in chicken manure is considerable.

As to the contrast of cultivars (TC, represented by cv Dardo against TB, represented by cv Santa Cruz-47), the significance was observed only for canopy diameter $(|\hat{y}|=18.1 \mathrm{~cm})$ and harvests number per production cycle $\left(|\hat{y}|=8.3\right.$ units cycle $\left.^{-1}\right)$, with advantage of cv Santa Cruz-47. This cultivar began to produce fruits later (70 days after seedling transplantation), however, as cv Dardo decreased its fructification, its fruit production intensified besides having extended the harvest, justifying the superiority in harvests number during production cycle. Moreover, it is a cultivar with a leafier canopy than cv Dardo, certified by greater canopy diameter.

Maximum economical efficiency dose - In an equivalence relation (0.98) wherein the acquisition of $1 \mathrm{~kg}$ of

Table 2. Treatments average values and absolute difference between mean of the treatments contrast (|ŷy) relative growth and yield characteristics of okra [médias de tratamentos e diferença absoluta entre médias dos contrastes (|ŷy) de tratamentos para características do crescimento e de produção em quiabeiro]. Manaus, Embrapa Amazônia Ocidental, 2010.

\begin{tabular}{|c|c|c|c|c|c|c|c|}
\hline \multirow{2}{*}{ Characteristics } & \multicolumn{4}{|c|}{ Averages } & \multirow{2}{*}{$\begin{array}{c}|\hat{y}| \\
\text { TAxTS }\end{array}$} & \multirow{2}{*}{$\frac{|\hat{y}|}{\text { TAxTC }}$} & \multirow{2}{*}{$\begin{array}{c}|\hat{y}| \\
\text { TCxTB }\end{array}$} \\
\hline & TS & TA & TB & TC & & & \\
\hline Plant height $(\mathrm{cm})$ & 28.1 & 36.6 & 39.0 & 37.3 & $8.5^{* *}$ & $0.7^{\mathrm{ns}}$ & $1.7^{\mathrm{ns}}$ \\
\hline Canopy diameter $(\mathrm{cm})$ & 54.0 & 79.4 & 105.6 & 87.5 & $25.4 * *$ & $8.1^{\mathrm{ns}}$ & $18.1^{* *}$ \\
\hline Harvests number (un cycle ${ }^{-1}$ ) & 21.5 & 25.5 & 33.3 & 25.0 & $4.0^{* *}$ & $0.5^{\mathrm{ns}}$ & $8.3^{* *}$ \\
\hline Fruits number (unit plant ${ }^{-1}$ ) & 14.9 & 30.7 & 40.7 & 35.0 & $15.8 * *$ & $4.3^{\mathrm{ns}}$ & $5.7^{\mathrm{ns}}$ \\
\hline Fruit average mass (g) & 13.5 & 16.7 & 17.0 & 17.5 & $3.2^{* *}$ & $0.8^{\mathrm{ns}}$ & $1.4^{\mathrm{ns}}$ \\
\hline Yield $\left(\mathrm{kg} \mathrm{ha}^{-1}\right)$ & 1356.3 & 3387.5 & 4510.4 & 4079.2 & $2031.2 * *$ & $691.7^{\mathrm{ns}}$ & $431.2^{\mathrm{ns}}$ \\
\hline
\end{tabular}

${ }^{* *}$ Significant at $1 \%$ of probability by $\mathrm{F}$ test and ${ }^{\mathrm{ns}}$ non-significant (significativo a $1 \%$ de probabilidade pelo teste de $\mathrm{F}$ e ${ }^{\mathrm{ns}}$ não significativo);

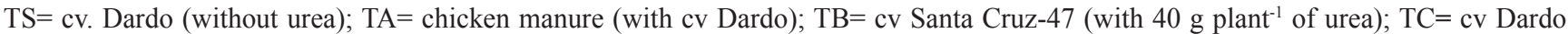
(with 40 g plant $^{-1}$ of urea) $[\mathrm{TS}=$ cv Dardo (sem adição de uréia); TA= esterco de galinha (com a cv Dardo); TB= cv Santa Cruz-47 (com 40 g planta $^{-1}$ de uréia); $\mathrm{TC}=\mathrm{cv}$ Dardo (com $40 \mathrm{~g} \mathrm{planta}^{-1}$ de uréia) $]$. 
Table 3. Effect of the variation regarding equivalence relation " $\mathrm{kg}$ of urea price (c) $/ \mathrm{kg}$ of fruits price in farmer condition (v)" on economical efficiency maximum dose (DMEE) of urea in topdressing and net income (RL) for the farmer, in okra culture under non-tightness spacing and residual fertilization [efeito da variação da relação de equivalência "preço do kg de ureia (c)/preço do kg de frutos de quiabo em nível de produtor (v)" sobre a dose de máxima eficiência econômica (DMEE) de ureia em cobertura e a renda líquida (RL) do agricultor, na cultura do quiabo sob espaçamento não-adensado e aproveitamento de adubação residual]. Manaus, Embrapa Amazônia Ocidental, 2010.

\begin{tabular}{lcc}
\hline $\begin{array}{l}\text { Equivalence relation } \\
(\mathbf{c} / \mathbf{v})\end{array}$ & $\begin{array}{c}\text { DMEE of urea in } \\
\text { topdressing } \\
\left(\mathbf{k g ~ h a}^{-1}\right)\end{array}$ & $\begin{array}{c}\text { Net income (RL) in equivalence } \\
\text { for the okra fruits per hectare } \\
(\mathbf{k g})\end{array}$ \\
\hline 3.90 & 261.93 & -3772.53 \\
2.02 & 265.75 & 0.00 \\
1.95 & 265.87 & 132.31 \\
1.30 & 269.83 & 1433.55 \\
0.98 & 267.87 & 2090.02 \\
0.78 & 268.27 & 2481.99 \\
0.49 & 268.87 & 3072.64 \\
\hline
\end{tabular}

urea would need $0.98 \mathrm{~kg}$ of okra fruit, the maximum economic efficiency dose (DMEE) would be 40.2 g plant $^{-1}$ of dressing of urea (Figure 2), and corresponded to $99.3 \%$ of the maximum agronomic efficiency dose (DMEA= $40.5 \mathrm{~g} \mathrm{plant}^{-1}$ of urea). The net income obtained per hectare in this price ratio, hiring outer labor, was 2.09 tons of okra, which represented $51.6 \%$ of gross income. Guimarães (2008) pointed out that the best net income for okra monoculture, density of 20,000 plants $\mathrm{ha}^{-1}$, equivalent to $50.93 \%$ of gross income.

In this study, the reduction of payment of each man day $^{-1}$, for the use of family labor, results in an increase of $26.5 \mathrm{~kg}$ of okra in the farmer income, which represents a "pro-labor of family agriculture". In the composition of the costs were accounted 45 man day ${ }^{-1}$, which corresponded to $70 \%$ of the production cost. It is noteworthy that to value this labor, the market value and the adding of labor costs were considered.

Because of the seasonality in the supply of okra in the regional market, the price per $\mathrm{kg}$ of fruits can range from $\mathrm{R} \$ 0.50$ to $\mathrm{R} \$ 4.00$, and it changes the ratio of the equivalence of the price of fertilizer to the price of the product, affecting DMEE and the net income (Table 3 ). In the ratio of 2.02 occurs the equivalence of the expenditure with the gross income, therefore, with net income equals to zero. Considering only the cost of the nitrogen fertilizer, in the density of 20,000 plants ha $^{-1}$, Oliveira et al. (2003) calculated the income of 8.5 $\mathrm{t} \mathrm{ha}^{-1}$ of fruits and a DMEE of $133 \mathrm{~kg}$ ha $^{-1}$ of $\mathrm{N}$, which would be equivalent to 6.65 g plant $^{-1}$ of $\mathrm{N}$, lower than the one obtained in this trial (18.09 g plant $^{-1}$ of $\mathrm{N})$, considering all the costs involved in production.

In the conditions of this study, in the Amazonian rainy season, all growth traits and the production of okra Dardo increased according to quadratic model with doses tested with urea, with general average doses (41.52 g plant $\left.^{-1}\right)$ practically the same of the maximum agronomic efficiency dose $(40.5 \mathrm{~g}$ plant $^{-1}$ ), which set ratio with yield of $4.05 \mathrm{t} \mathrm{ha}^{-1}$ of fruits of okra Dardo. This cultivar responded positively to organic fertilization with chicken manure, with the same performance of that one obtained with urea and higher than the one obtained in the treatment without urea, for all the traits. $\mathrm{Cv}$ Santa Cruz-47 denoted higher architecture and, although it was later, it had higher number of harvests per production cycle than cv Dardo. For moderate yield, justified particularly for slightly thickened space, in a diversified potential system of vegetable production of farmers, DMEE was 40.2 g plant $^{-1}$ of dressing of urea (120.6 kg ha-1 of N), in a equivalence ratio in which to acquire
$1 \mathrm{~kg}$ of urea would be necessary $0.98 \mathrm{~kg}$ of okra fruits. This dose corresponded to $99.3 \%$ of DMEA ( $40.5 \mathrm{~g} \mathrm{plant}^{-1}$ of urea), culminating in net income per hectare, in this price ratio, corresponding to 2.09 tons of okra, which represented $51.6 \%$ of the gross income. In the context of repetition of this trial during the Amazonian rainy season, the growth and yield of okra may respond with maximum values in lower doses of urea than those ones tested in this study, because the dynamics of this nutrient in soil is influenced by different factors, especially by wetting and drying of the soil, denoting necessity of future studies.

\section{ACKNOWLEDGEMENTS}

The authors are thankfull to FINEP by research support

\section{REFERENCES}

ALMEIDA DL. 1991. Contribuição da adubação orgânica para a fertilidade do solo. Seropédica: UFRJ. 192f. (Tese doutorado).

ANDRIOLO JL. 2002. Olericultura geral: princípios e técnicas. Santa Maria: Ed. UFSM. $158 \mathrm{p}$.

ARAUJO WO; COELHO CJ. 2009. Análise de componentes principais (PCA). 11p. Disponível em: http://www.unievangelica. edu.br/gc/imagens/file/mestrados/artigos/ RTINF_003092.pdf Acesso em 19 de maio de $201 \overline{1}$.

BAYER C; MIELNICZUK J. 1999. Dinâmica e função da matéria orgânica. In: SANTOS, GA; CAMARGO FO (eds). Fundamentos da matéria orgânica: ecossistemas tropicais $e$ subtropicais. Porto Alegre: Gênesis. p. 9-26.

CAMPOS VB; OLIVEIRA AP; CAVALCANTE LF; PRAZERES SS. 2008. Rendimento do pimentão submetido ao nitrogênio aplicado via água de irrigação em ambiente protegido. Revista de biologia e ciências da terra 8: 72-79.

CARDOSO MO. 2001. Desempenho de cultivares de quiabo em condições de terra firme do estado do Amazonas. In: CONGRESSO BRASILEIRO DE OLERICULTURA, 41. Resumos... Brasília: SOB (CD-ROM).

CONAB. Companhia Nacional de Abastecimento. 2010. Custos de produção agrícola: a metodologia da Conab. Brasília: CONAB. 60 p. Disponível em: http://www.conab.gov. br/conab/Main.php?MagID=3\&MagNo=39. Acessado em 25 de maio de 2011.

COSTA MCB; OLIVEIRA GD; HAAG HP. Nutrição mineral de hortaliças. Efeito da omissão dos macronutrientes e do boro no desenvolvimento e na composição química do quiabeiro. In: HAAG HP; MINAMI K. 1981. Nutrição mineral em hortaliças. Campinas: 
Fundação Cargill. p. 257-275.

DUARTE FM. 2006. Perdas de nitrogênio por volatilização de amônia e eficiência de adubação nitrogenada na cultura do arroz irrigado. Santa Maria: UFSM. 87p. (Dissertação mestrado).

DUARTE TS; PEIL RMN. 2010. Relações fonte:dreno e crescimento vegetativo do meloeiro. Horticultura Brasileira, 28: 271276.

FISCH G; MARENGO JA; NOBRE CA. 1998. Uma revisão geral sobre o clima da Amazônia. Acta Amazônica 28: 101-126.

FAO CORPORATE DOCUMENT REPOSITORY. 2003. Melhorar a nutrição através das hortas familiares. Roma: FAO. 297p. Disponível em: http://www.fao.org/docrep/007/x3996p/ x3996p18.htm Acessado em 31 de março de 2011.

FILGUEIRA FAR. 2008. Novo manual de olericultura: agrotecnologia moderna na produção e comercialização de hortaliças. 3 . ed. Viçosa: UFV. 421 p.

FONTES PCR. 2005. Olericultura: teoria e prática. Viçosa: UFV. 486p.

GOMES MAF; SOUZA MD; BOEIRA RC; TOLEDO LG. 2000. Nutrientes vegetais no meio ambiente: ciclos bioquímicos, fertilizantes e corretivos. Jaguariúna: Embrapa Meio Ambiente. 50p. (Embrapa Meio Ambiente. Documentos 18).

GONSALVES PE. 2001. Livro dos alimentos. São
Paulo: MG Editores. 266p.

GUIMARÃES AFR. 2008. Rendimento agronômico de quiabo e cebola em consórcio e monocultivo. Janaúba: UNIMONTES. 63p. (Dissertação mestrado). Disponível em: http:// www.dominiopublico.gov.br/download/texto/ cp105747.pdf. Acessado em 01 de junho de 2011.

IDAM. Instituto de Desenvolvimento Agropecuário e Florestal Sustentável do Estado do Amazonas. 2010. Tabelas de acompanhamento trimestral da produção vegetal, 2010: hortaliças. Manaus: SEPROR/ IDAM. $17 \mathrm{p}$.

LONGO RM; MELO WJ. 2005. Hidrólise da ureia em latossolos: efeito da concentração de ureia, temperatura, $\mathrm{pH}$, armazenamento e tempo de incubação. Revista Brasileira de Ciência do Solo 29: 651-657.

MALAVOLTA E; PIMENTEL-GOMES F; ALCARDE JC. 2002. Adubos e adubações. São Paulo: NOBEL. 200p.

MAMBER, D. 2011. Niacina, a vitamina do HDL. Disponível em: http://saude.abril.com.br/ especiais/colesterol/conteudo_274682.shtml Acessado em 26 de maio de 2011 .

MARSCHNER H. 1995. Mineral nutrition of higher plants. 2. ed. London: ACADEMIC PRESS. $889 \mathrm{p}$.

MENGEL K; KIRKBY EA. 1987. Principles of plant nutrition. 4. ed. Bern: International Potash Institute. $687 \mathrm{p}$.
OLIVEIRAAP; ALVES AU; DORNELAS CSM; SILVA JAS; PÔRTO ML; ALVES AU. 2003. Rendimento de quiabo em função de doses de nitrogênio. Acta Scientiarum Agronomy 25: $265-268$.

QUEIROGA RCF; PUIATTI M; FONTES PCR; CECON PR; FINGER, FL. 2007. Influência de doses de nitrogênio na produtividade e qualidade do melão Cantalupensis sob ambiente protegido. Horticultura Brasileira 25: 550-556.

RAIJ BV. Fertilidade do solo e adubação. 1991. Piracicaba: Ceres/Potafos. 343p.

RIBEIRO AC; GUIMARÃES PTG; ALVAREZ V, VH (eds). 1999. Recomendações para uso de corretivos e fertilizantes em minas Gerais $-5^{a}$ Aproximação.Viçosa: CFSEMG. 359p.

SEDIYAMA MAN; SANTOS MR; VIDIGAL SM; SALGADO LT; PEDROSA MW; JACOB LL. 2009. Produtividade e estado nutricional do quiabeiro em função da densidade populacional e do biofertilizante suíno. Bragantia 68: 913-920.

SOUSA DMG; LOBATO E (eds tecs). 2004. Cerrado: correção do solo e adubação. 2. ed. Brasília: Embrapa Informação Tecnológica. 416p.

TAIZ L; ZEIGER E. 2004. Fisiologia vegetal. 3. ed. Porto Alegre: ARTMED. 719 p.

TOMÉ JUNIOR JB 1997. Manual para interpretação de análise de solo. Guaíba: Agropecuária. 247p. 